\title{
The Examination on African American's Delayed Dream through the Analysis of Langston Hughes' Jazz Poetry
}

\author{
Mia $\mathrm{Kim}^{1}$ \\ ${ }^{1}$ Associate Professor, Superstar College,Jeonju University, Korea,kmial4@nate.com
}

\begin{abstract}
Abstract: What sets Hughes' musical poetry apart from those of others is that his poems faithfully embody the forms and themes of the music he pursues and its evolution process, without partially borrowing or embodying musical elements superficially. This research will analyze Hughes' boogie woogie poems and bebop poems compared with the typical format of blues and jazz, which have been the representative and symbolic music to African Americans. This paper will first examine the spiritual element of jazz and blues that represents African American's periodical emotion in American history through the gradual growth and change of a greatest black poet Langston Hughes' ideology and poetry. With the examination of Hughes' various experimental techniques and literary skills proven in his different poems, this study will reflect African American's desire for their delayed dream to come true which is to be completely free and positive even in all the yoke of chaotic American history. Based on the concrete analysis of African American's typical dialect, their true language being used in their daily lives, this study will also discuss on the accomplishment of black aesthetics in Hughes' pomes which was his final goal as a writer. This research will look into the social theme and psychological colonialism embraced in his poems. As a result, this paper will suggest black's unique aesthetic identity Hughes tried to embody in all his life. For that purpose, this study will adapt the theory of George M. Fredrickson and Lawrence Levine for the exploration of black culture and black's unique consciousness, and the theory of J. Tolson for the analysis of Langston Hughes' jazz poems methodologically. This research intends to reinterpret African American's own aesthetics, and to propose another chance for diverse races coexisting in America to understand each other's characteristic.
\end{abstract}

Keywords: Social Theme, Dialect, Be-bop, Boogie-woogie, Montage Technique, Black Aesthetics

\section{Introduction}

The matter of African American's lives survival, equal right as a human being and economic stability is still not solved yet. It's a pending issue in American society which faces another racial crisis. The reality of a weary and impoverished life of blacks and their trapped soul show a vicious cycle under the white people's vested right[1]. There have been countless black writers who had embraced African American's mourning, devastation, heartbreaking emotion in their art works within the connectivity of black music, and they tried hard to shed light on such aesthetic sentiments by highlighting the positive aspects of African Americans[2]. Among them, there is Langston Hughes who was called a poet of black people.

This study will examine the social, cultural, and innate background of Langston Hughes' basic interest in music poetry. In the early 1920s, as American society was going through an economic panic, Hughes began to reflect the misery of black people's lives in blues format, which had become more unstable and

Received: August 06, 2020; $1^{\text {st }}$ Review Result: September 24, 2020; $2^{\text {nd }}$ Review Result: November 11, 2020 Accepted: December 28, 2020 
bloodier until the early 1930s. Blues' basic emotions were based on depression, ominousness and negative aspects. Hughes expressed such sentiments by embodying them into his own blues poems, which contain the form and content of blues music[3]. It is true that Hughes dealt with many blues formats and themes in his poems, but his starting point as a poet was from jazz. The two genres of music, blues and jazz basically share black spirit. However, while blues truly captures the emotions of black people, jazz contains more colorful and exotic emotions including whites' emotion by accepting various musical elements from different regions. In other words, jazz is a more open form of music to various people and culture than blues. It is the reason this research chose to examine Langston Hughes' poems for the analysis of African American's true aesthetics and their identity.

This study will analyze Langston Hughes' 'jazz poems', which were originally born in the frame of openness and freedom. It will explore the new experimental challenges and the meaning of Hughes' poems, through the analysis of their formal and technical aspect. The significance of this study is to explore African American's unique sentiments through the examination of Hughe's jazz poems. For this purpose, this paper intends to shed the light on the value of black people's intrinsic oral tradition, especially music, which had been regarded as a low level of culture ignoring the formality and concreteness. African American's oral music including blues, jazz, bebop, and boogie-woogie can be the synthetic output that integrates and completes musical formality with the specific experimental process through the examination of Langston Hughes' poems.

In terms of methodology, what this research aims to do is to clarify the basic form and values of jazz and to analyze Langston Hughes' representative collection of poems, "The Montage". "The Montage" is the result of the proper combination of content and formality. Regarding the content, this paper targets to analyze the significance of black music and the political and historical background of its driving force in the connectivity of African American's ethnicity in the same perspective of Fredrickson and Lawrence Levine. Concerning the analysis of musical factor in Langston Hughes' poetry, this paper applies to proceed the research in the same view point of J. Tolson.

\section{Hughes' Poetic Ideology}

Langston Hughes' poetry is full of dynamic power. In this chapter, this study will examine Langston Hughes' ideological challenge, growth and change as an artist. Based on the exploration of the language of music Langston Hughes used, this study examined how Hughes tried to capture the suffering history of African Americans in American society and embodied African American's desperation to overcome the suppression and devastation with their positive mind. For the purpose of the examination and analysis of it, this chapter will first approach on looking into Hughes' spiritual growth and change. In the early period as an artist, Hughes could not convey the black's identity to readers through his workds. He did not establish his own literary skill to express his ideology. However, while he traveld many places, especially in a club in Paris, he encountered several jazz masters in his early 30s. Ever since the moment, Hughes was deeply absorbed in the power of jazz. The magic of jazz having the characteristic of improvisation, unfixed development, and free style made Hughes choose its format to reflect African American's life and their philosophy[4].

With this reason, this study will examine the meaning of black music, especially jazz for Langston Hughes. Then it will analyze the process of Hughes' ideological conficts following the footsteps of his spiritual growth and change.

In Langston Hughes' poems, the musical rhythm itself delivers an important message, as well as the content. Hughes' message if based on the introduction of black music in his work, enabling him to sublimate into a tribal and folk message rather than an individual, and has historical and visionary elements to future generation. The characteristics of Hughes' work is that he uses black music in his 
poetry to express historical, social, or spiritual experiences shared by the entire black as a language art called poetry. The soul that Hughes talks about is literally the core of the black spirit, the tribal consciousness of suffering and suffering, and at the same time their representative form of music. The fact that the soul and music form a close relationship to have the same meaning is an important factor that should never be overlooked in studying Hughes' poems and other black writers' works. In explaining his art, Hughes defined the core of blackness as soul, which he defines as the essence of black folk art. Black music, such as, blues, bebop and jazz, developed after black spirituals, was a spiritual symbol of black people and another language that represented their identity.

Black music is the rhythm of black people's lives. From a long time ago, black people gained the power of life from their music. When African Americans were led to the New World by the bodies of slaves, their music landed with their souls. From slavery until now, music has been a consolation to the souls and bodies of the severed and wounded black people. Music was the refuge of a poor life, the instrument of ecstasy, the symbol of the transcendent beauty of hard life, and the conviction. The daily rhythm of persecuted and oppressed black Americans were the rhythm of jazz, and their lives were heavily shaded with blues rhythm. Just as black music cannot be separated from the lives of the black people, the form and theme of Hughes' poems are another expression of the art and spirit of black music. Hughes, who had experienced black music from a very early age, used black music as the foundation for poetry creation.

The source of Hughes' poetry is based on the emotional unity between himself and the black people. Hughes found his poetic theme in the pain and pleasure of life that the black people were going through, and derived his philosophy of life and literature from their philosophy and culture. Therefore, his poems reflect the social and political situations of the black people of the time.

This study seeks to observe in depth the close relationship between black music and Hughes' works to explore how such organic relationships reflect the political and social situations of blacks. The ideological trends that emerged in the early 20th century, especially from the early 1920s through 1960s, when Hughes was vigorously publishing his poems, are generally divided into three main categories. They are 'Assimilationism', 'black nationalism', and 'radicalism'.

Black-and-white assimilators argued that they could acquire certain black rights and interests in American society without a fundamental social change in social structure. Their argument had considerable appeal to the middle class black people, who had a strong desire to become the middle class. Those who were able to maintain relative economic stability and possibility rise in rank emphasized that black people could pursue a harmonious life between black and white by acting like white people.

The fundamental goal of the framework was to secure an independent living space for black people, with the idea that not only economic but also political and cultural influence can be exerted by establishing a black-only economic community. Radicals argued that without fundamentally changing the political and social structure of the Untied States, Americans could not improve their situation. Without doing so, they stressed that not only could the claims of black-and-white assimilationists or black-and-white nationalists not be realized, but that it was impossible to build an independent, selfsufficient community. Their goal was to find out the source of power in American society and make allout efforts in the struggle to gain the center of power and to turn capitalism into socialism.

Hughes was more sensitive to the social and political trends of his time than anyone else, but he was not inclined to either side. However, as a writer, he constantly tried to embody the realistic and political situation of the black people in his poetry by putting it in the melody of black music throughout his life. Hughes was also the owner of a complex vision. He approached the essence of the problem in his own way while maintaining a constant distance without directly or deeply intervening in any event or problem. Therefore, it can be said that the deep approach to maintaining distance suggests another feature in Hughes' poetry. 
His poems are prone to remain tense in terms of African American's circumstance and the stream of literature. In other words, Hughes' poems have pursued the problem of blackness, racism, conflict in a white-centered society, tension with radical ideology, and balance between lyricism and satire are always tense. Another characteristic of Hughes' poetry is personal, but it can be said to reflect the duality of the black American people at the time. Through this complex vision of his own, Hughes sought to express in greater depth the pain and hardship of his fellow nations suffering. Most of all, music flowing like a river in his poetry produces a powerful force that awakens the people and unifies them as one.

A sociologist and art critic, W. E. B. DuBois led the black consciousness movement through the magazine "The Crisis" as the leader of the most important black movement of the early 20th century. He is also the most influential spiritual teacher in Hughes' ethnic literary world. Through the first chapter of the book "The Souls of Black Folk", he mentions the terms and cencepts of dual consciousness as follows. uniform.

It is a peculiar sensation, this double-consciousness, this sense of always looking at one's self through the eyes of others, of measuring one's soul by the tape of a world that looks on in amused contempt and pity. Oen ever feels his two-ness, -an American, an Negro; two souls, two thoughts, two unreconciled strivings; two warring ideas in one dark body, whose dogged strength alone keeps it from being torn asunder[3].

DuBois regarded these two egos as a spiritual legacy that he could not abandon, and he did not intend to turn America into Africa, nor did he intend to bleach the soul of the black in a flood of white Americanism. He only wanted to be American and black at the same time. In other words, dual identity itself was taken as black identity. The concept of double consciousness presented by DuBois served as a cornerstone in moving beyond 'assimilationism' asserted by revisionists like Booker T. Washington and 'separatism' asserted by nationalists like Marcus Garvey, despite the tensions and uncertainties inherent in it. Since then, the concept has been widely used in all discussions concerning the issue of black and white, and has become the most essential element, especially in black literary criticism. Gates developed this into a concept of double-voiced text, making it a common theory favored by feminist and minority writers as well as black writers[5]. Thus, this concept of complex consciousness is not only applied to minority groups but also to the general situation of the duality of American culture.

Hughes' pursuit of black aesthetics is closely related to overcoming this dualism to establish the identity of black art. In his essay "The Negro Artist and the Racial Mountain", which has the nature of a declaration on this issue, Hughes stressed that by emphasizing the oral tradition that black Americans have kept, they can stick to the identity of black art. His poetic attitude and artistic spirit contributed greatly to the change in black consciousness. Hughes has contributed to the establishment of African American aesthetics and exerted great influence on the growth and change of African-American consciousness by using his own sensibility, theme, form, usage and style. Likewise in this chapter, this study have explored Huhges' ideological growth and interest and his literary influence.

\section{Hughes' Bebop Poem Reflecting Social Theme}

After dropping out of Columbia university and wandering around the world for a while, Hughes works for a small club in Paris, where he builds up a close relationship with jazz music. The meeting with jazz masters in Paris brings Hughes to express his deep appreciation of jazz music in poetry. The "cabaret poem' of Hughes is an early form of Hughes' jazz poetry. "Jazzonia", "Jazz Band in a Parisian Cabaret", "Negro Dancers", "Lenox Avenue: Midnight” are good examples of Hughes' early poems. Hughes says "life's rhythm is jazz' rhythm" in "Lenox Avenue: Midnight", and it proves that Hughes was completely indulged in jazz at that time. For Hughes, the rhythm of jazz was the heartbeat of black people and a cry that made them go beyond depression[6]. 
The difference between jazz poem and blues poem, in which Hughes captures the emotions of African American people, is that blues poetry reveals the form of blues on the surface, while jazz poetry does not reveal the musical elements of jazz as it is. Unlike blues poems, where poetry and music are harmonized in many aspects, jazz poems are hard to find a match for one another. Jazz poetry is a free poem with no fixed form, which captures the free and spontaneous atmosphere and image of jazz music.

The dynamic power of jazz music is very different from the quiet and gloomy atmosphere of blues music. Because jazz has an instrumental vitality, the sentences in jazz poems are informal, concise, and short passages. They are also expressed in a speedy way. These aspects are well illustrated in Hughes' poems, "Negro Servant" and "Railroad Avenue". These poems pursue the form of open poetry free of rhyme or rhythm, and advocate the impromptu nature of jazz. The language of jazz poetry, including an unconventional dialogue, shows the spontaneity of his thoughts and feelings, such as jazz improvisation.

Starting from poets like Walt Whitman, Lindsay, Sandberg, jazz poetry was a process of finding the primitive rhythm of American poetry. Looked into the genealogy of jazz poetry in the history of black literature, Paul Laurence Dunbar's dialect poetry is its pioneer based on black painting in the Southern countryside. After Dunbar's death, Lindsay took over his status as a representative jazz poet, and later Hughes followed them as his literary model to start his jazz poems. Hughes' "Song for a Banjo Dance" was affected by Dunbar's "A Negro Love Song", and his "Harlem Night Club" and "A Jazz Band in a Cabaret in Paris" were affected by Sandberg's "Jazz Fantasia". As such, Hughes developed jazz poetry independently to make it more artistically perfect after being influenced by his senior poets.

Hughes often uses jazz to refer to general black music, not to a particular genre of music. With jazz, he sought to complete black spirit and black aesthetics, that is the essence of blues and all other musical cultures. To Hughes, jazz was a huge sea where black people's essential music was all gathered in. Hughes' jazz poetry has a complex meaning that encompasses all the facts related to black music, including blues poetry. Having considered the rhythm of life and the rhythm of jazz as one, Hughes saw jazz as a new and free interpreted output of the complex history of life, not just an entertainment[7]. In his bebop poems, he tried to capture the moment of everyday life in jazz, and show the rhythm of life which was not separated from it. Hughes embraced joys, sorrows and resistance of black people hidden behind the swirling jazz into his poems. In Hughes' jazz poems, the painful history of the slavery and the anxiety of deferred dream for black people's future is flowing like a deep river on the basis of bebop rhythm which seemingly cheerful and emptily pleasurable.

Frustrated by the capitalist order that had stimulated racism and exploitation of labor, Hughes once tried to find an alternative in communism to accomplish black's dream. However, Hughes realizes that there is no such ideology that is not related to race and nationality. The ideology that the Harlem Renaissance pursued is not losing the root of black people's life history even though it had been struggle. It pursues laughter and romance even in sorrow. As Hughes was aware of the entity of communism, he breaks away from the radical line in his literary work. Ever since the experience, Hughes feels more social responsibility as a writer and tries hard to combine social theme in the form of music poems.

The poem, "Montage of a Dream Deferred", is the one that Hughes' poetic perspective on it was culminated. In this poem, Hughes deals with social theme of a dream that has been delayed without a promise through the musical form of boogie-woogie and bebop by using the technique of 'montage'. In Hughes' poems, dreams symbolize political freedom and economic stability than romantic fantasy or desire. The delayed dream leads to black people's political inequality and economic discrimination. Hughes examines these social chaos and inequality in his poems in a various ways of experimental technique.

'Montage' is originally meant to be assembled or matched, usually a composite photograph made by assembling a few photographs. In 1915, Germany's dadaists, who were inspired by French collage techniques, created an unrealistic and fresh image by putting together several unrelated photos on the same screen. Since then, the technique has been further developed for the covert purpose of agitation, 
being used as a metaphorical means of resistance to Hitler's Nazi regime. In particular, in the movie, Montage technique was able to achieve emotional effects such as empathy, contrast, emphasis, and satire by replacing a series of films taken separately at a rapid pace. This includes, for example, a technique that highlights the cruelty of war by inserting animal slaughter scenes from the middle of the war scene. The adaptation of montage techniques to literature gives the impression that seemingly unrelated scenes are unified by afterimage effects or awakening, and it can gain the effect of 'free association' that tracks the flow of consciousness. That is to say, the fragmented consciousness that was subconsciously latent becomes uniform[8].

In terms of current African-American popular music and the sources from which it has progressedjazz, ragtime, wing, blues, boogie-woogie, and be-bop-this poem on contemporary Harlem, like be-bop, is marked by conflicting changes, sudden nuances, sharp and impudent interjections, broken rhythms, and passages sometimes in the manner of the jam session, sometimes the popular song, punctuated by the riffs, runs, breaks, and distortions of the music of a community in transition.

As such, Hughes tries to explain all the new musical elements he chose in relation to the characteristics of bebop. All his bebop poems have continuity like a link. The titles of these poems are organized with the method of jam session in bebop music. Jam session is a way of exchanging impromptu performances with several performers, and individual improvisations are performed within the promised theme. Each improvisation creates a new musical theme[9]. Bebop's jam session, which seeks to release the rhythm temporarily through improvisation, is the musical version of montage technique. Likewise, Hughes emphasizes black people's unrestrained right, and he showed his will as a black writer in the free form of jazz poetry pursuing the liberation of rhythm and rhyme.

With the effect of montage technique, Hughes also quotes the sound of drums as the driving force behind the strong viability of African Americans in his bebop poem, "American Negro Leader".

Subdued and time-lost

Are the drums - and yet

Through some vast mist of race

There comes this song

I do not understand

This song of atavistic land,

Of bitter yearning lost

Without a place-

So long,

So far away

Is Africa's[10].

For African Americans, the United States is not a land that has been inherited from their ancestors, but a atavistic land that has been inherited from their ancestor slaves. The sound of drums, a primistive rhythm of native West Africa, is the source of jazz rhythm, and the rhythm of jazz is the representation of the black faces of Africa. Although African Americans lost their good days in Africa enjoying freedom and richness, their songs are still alive and their lives are continued. Jaa is a means of enduring the present survival and future hope of black people.

For African Americans, jazz plays a role of minstrel who endures many years of pain and adversity and pass on their experiences and dreams to future generations. Jazz music embraces African American's history and their dreams, as if 'black mother', who was dragged to America from the land of African there hundred years ago, has been beaten and mistreated, but she persistently maintains a dream like steel.

Likewise Hughes wrote quite volumes of bebop poems including social themes consoling African 
American's scar in their deep heart. As they tolerate slavery and subsequent years though drumming, singing, and jazz, African Americans gradually take off their feature of clown and shout at the world like the speaker in "The Black Clown", declaring themselves human.

\section{You laugh}

Because I'm poor and black and funny-

Not the same as you-

Because my mind is dull

And dice instead of books will do

For me the play with

When the day is through.

I am the fool of the whole world,

Laugh and push me down.

Only in song and laughter

I rise again — a black clown.

A slave - under the whip,

Beaten and sore,

God! Give me laughter

That I can stand more.

Cry to the world

That all might understand:

I was one a black clown

But now-

I'm a man![11]

This poem, which begins with the premise, "A dramatic monologue to be spoken by a pure-blooded Negro in the white suit and hat of a clown, to the music of a piano, or an orchestra", is a poem that shows the technique of Hughes' bebop poetry[12]. Poetic techniques that place lines on the right and set the mood of the poem on the left are prominent in these poems, "The Colored Soldier", "Broke", "The BigTimer", "12 Moods for Jazz".

This first verse fo the poem, which starts with a cheerful but low-pitched blues rhythm, continues to vividly depict the blurry, pathetic, and ridiculous black speaker as if the circus clowsn are jumping here and there with funny gestures on stage. In order to embody the daily life of a black man, not holding a book, but holding a dce in the poem, Hughes connects it to a melancholy jazz rhythm with humourous yet rebellious attitudes and tones to effectively convey such images to listeners. In "I will get back on my feet", Hughes firmly delivers his message that the oppressed and isolated people have to led their life to be out of the shackle with their own struggle. Hughes argues that black people should win their rights through their own struggles, and he ultimately pursues to make the world, where not just the black people, but all races understqand and reconcile with each other[13].

This is the poem in which Hughes' ideology is intensely revealed. Hughes dreams of a world full of peace, love, and blessings, and equal benefits of the products of the earth, whether black or white. 
I dream a world where man

No other man will scorn,

Where love will bless the earth

And peace its paths adorn.

I dream a world where all

Will know sweet freedom's way.

Where greed no longer saps the soul

Nor avarice blights our day.

A world I dream where black or white,

Whatever race you be,

Will share the bounties of the earth

And every man is free[14].

\section{Hughes' Boogie-woogie Poem Embracing Black Nation's Ethnic Sentiment}

As stated in the preface of ${ }^{『}$ Montage $e_{\rrbracket}$, this collection of poems is based on bebop as its motif, but it is based on the tradition of blues. The two of blues poems, "Blues at Dawn" and "Same in Blues" sing about the delayed dreams of black people. Hughes adopts boogie-woogie as a major motif along with bebop to his bebop poems. Hughes' six boogie-woogie poems, "Dream Boogie", "Boogie 1 a.m.", "Lady’s Boogie", "Nightmare Boogie", "Dream Boogie: Variation" are the core parts of ${ }^{\circledR}$ Montage $\lrcorner$.

As Hughes mentions in the preface, boogie-woogie poems are arranged at appropriate intervals throughout the collection to support the subject. These poems are as detailed as bebop technique[15]. In the perspective of music history, boogie-woogie has a high degree of perfection of blues by forming a junction between blues and jazz, but also has more vitality by using instrumental music. It plays significant role in the birth of bebop. Hughes' these six boogie-woogie poems are the ones containing the development process of bebop and embodying the form of bebop into poems.

The biggest musical feature of boogie-woogie is that it uses 'ragtime'and 'walking base' accompaniment to continue to play the variation of blues. It shows blues variations with its left hand, and it shows melody with improvisation and 'syncopation' with its right hand based on boogiewoogie.Frustration, misery and hope of the delayed dream dominating the consciousness of black people are excellently expressed in the poem, "Dream Boogie", which is composed of the low rumbling sound of the walking base, which is played by boogie-woogie's left-hand accompaniment. The continuous ringing of this sound is the theme music and, at the same time, background music that dominates the whole poems[16].

Good morning, daddy!

Ain't you heard

The boogie-woogie rumble

Of a dream deferred?

Listen closely:

You'll hear their feet

Beating out and beating out a -

You think

It's a happy beat?

Listen to it closely? 
Ain't you heard.

Something underneath

like a -

What did I say [17]

From a musical standpoint, it can be said that it corresponds to an irregular rhythm of boogie-woogie off the blues format. These parts, in musical form, will be played by sudden 'repetitive sentence, decorative phrase, break' etc. It should be played on its right hand if it is played on piano. The poetic effect that Hughes seeks to achieve through this combination of successive questions and intermittent rhythms, is to remind them of the seriousness of delayed dreams of black people and the social and structural contradictions[18]. Hughes expresses a complex and confused state of mind disguised as happiness by making an anomalous exception in the poem, which originally had the form of three paragraphs, twelve lines, twelve phrases[19].

The poem, which presents the original form of the other five poems, not just here, but by adding more experimental elements, heralds the arrival of bebop poetry. As the preface mentions, an ending with 'an unexpected difference in meaning and a sharp and rude exclamation' marks the end of the poem[20].

\section{Sure \\ I'm happy! \\ Take it away! \\ Hey, pop! \\ Re-bop! \\ Mop! \\ Y-e-a-h![21]}

In this poem, the ending line expresses the speaker's intention to overcome the original misfortune of dream frustration and depression[22]. "Hey, pop!/ Re-bop!/ Mop!"following each rhyme is a kind of black dialect that contains various elements of musical expression. While the dialect that often appears in blues, such as 'daddy, papa, pop', or 'mama', contains a little vulgar meaning, Hughes continues to use these dialects in his poems, showing his seriousness toward African American's oral tradition. The use of such dialects also strengthens the homogeneity of black people, allowing them to convey Hughes' own sincerity more effectively[23]. Hughes uses the title 'daddy, papa, pop' to suggest that the speaker of the poem is a woman, and he clearly asserts that the delayed dream is a common theme of not only men but also all black people, including women.

\section{Conclusion}

Hughes' jazz poetry made an important contribution to the building of African American aesthetics through the art form of black people. Hughes, who enjoyed meeting black people in person through music plays and poetry recitals, tried to express the true language and dialect of black people in his poems, thereby helping black people overcome psychological colonialism[24]. Through the complicated and long experimental journey, Hughes could suggest the cornerstone of African American's own aesthetic identity. As a result, this study concludes that African American's oral music including blues, jazz, bebop, and boogie-woogie was the synthetic output that integrates and completes African American's musical experiment and tradition, and their spiritual restoration. 
This study proves that Langston Hughes tried hard to represent the ethnic sentiments of black people through jazz poems. It tried hard to shed the light on the value of black people's unique oral tradition, especially music, which had been regarded as a low level of culture ignoring the formality and concreteness. It will be the way to understand and to accept the unique culture and fundamental consciousness of blacks without any prejudice. African American's music has been an important basis for the formation of black identity among the unique cultural heritages of black people, and as Lawrence Levine notes, it is a key element of black positivity that has given African Americans dreams and hopes for the future[25]. Jazz poetry pursuing the sense of the unconventional and free spirit has very similar format of jazz music. It reflects black culture and black own identity on the basis of jazz music. Black people's music and poetry, embracing the dreams and hopes of black people who have been constantly frustrated and refused, capture such gloomy and dark side of the reality, but they, simultaneously, capture the humor of tragedy and comedy in their life.

In this regard, this study on Hughes' jazz poetry is of considerable significance. This research tried hard to examine the process of technological change and harmony manifested in Hughes' jazz poetry based on the methodological application of Tolson's theory.

African American's deep pain caused by the delayed dream is that it cannot be predicted how long it will last. Over the course of a day or two, black people's hearts have dried up, hardened, and eventually festered. It is hard for black people to keep their anger unexploded in the reality. This study tried hard to reflect and analyze African American's dual adversity and their social psychology with the analysis of Langston Hughes' poems having jazz factors of improvisation, diversity, and freedom. However, this study has the limitation that it only considered a few representative poems to cover the overall influence of jazz and blues poetry in the history of American literature. For future research, this study will compare and analyze jazz and blues poems by more diverse artists. The issue of African Ameircan's human right to live their life in American society is a heavy topic that is still unresolved. This study concludes in anticipation of the wind of change in American society that acknowledges true freedom and true diversity.

\section{References}

[1] Collier James L.,"Jazz", The New Grove Dictionary of American Music, Vol II. Eds. H. W. Hitchcock \& Stanley Sadie. 1st ed, Macmillan Publishers Ltd., (2006)

[2] Bloom, Harold, Ed. Langston Hughes: Comprehensive Research and Study Guide. Broomall, Chelsea House Publishers, (1999)

[3] R. Baxter, The Art and Imagination of Langston Hughes, The University Press of Kentucky, (2006)

[4] Oliver, Paul, "Blues”, The New Grove Dictionary of American Music, Vol I. eds. H. W. Hitchcock \& Stanley Sadie. 1st ed, Macmillan Publishers Ltd., (2001)

[5] DuBois, W. E. B. The Souls of Black Folk, A Norton Critical Edition, W. W. Norton \& Company, Inc., (1999)

[6] Cherki, Alice, Frantz Fanon, Portrait par Alice Aheriki, Editions du Seuil, (2000)

[7] Steven C. Tracy, Langston Hughes and the Blues, University of Illinois Press, (2001)

[8] Giles Townsend Cheryl, Identity Politics or Grounded Theory: Revisiting Black Feminism Ideas, Contemporary Sociology, (2000), Vol.29, No.5, September.

[9] Baraka Amiri, Blues People, 1st Quill edn, Harper Collins Publishers, (1999)

[10] Mark Tucker, "Jazz”, The New Grove Dictionary of Music and Musicians, Ed. Stanley Sadie, Macmillan Publishers, (2001), Vol.12, pp.903-904. 
[11] Young Kelvin, Ed. Blues Poems, Everyman's Library, (2003)

[12] George M. Fredrickson, The Black Image in the White Mind, Wesleyan University Press, (2007)

[13] Lawrence W. Levine, Black Culture and Black Consciousness: African-American Folk Thought from Slavery to Freedom, Oxford University Press, (2007)

[14]Hughes Langston, The Collected Poems of Langston Hughes, Eds. Arnold Rampersad \& David Roessel, Vintage Books, (1994)

[15] Nancy Bonvillain, Language, Culture and Communication: The Meaning of Messages, 4th edn. Upper Saddle River., Pearson Education, (2003)

[16] Jeffrey Charles Alexander, Cultural Trauma and Collective Identity, University of California Press, (2004)

[17] Candice M Jenkins, Queering Black Patriarchy: The Salvific Wish and Masculine Possibility in Alice Walker's The Color Purple, Modern Fiction Studies, (2002), Vol.48, No.4, pp.969-1000.

[18] J. Tolson, Jazz Style and Articulation: How to Get Your Band or Choir to Swing, Music Educators Journal, (2012), Vol.99, No.1, pp.112-123.

[19] Brooks, Dawn Elizabeth, Vocal jazz repertoire from 1920-1960: A Selection of unpublished repertoire by the Mills Brothers, the Boswell Sisters, and the Hi-Lo's for use in classical programming, Doctor of Musical Art University of Southern California, (2009)

[20] Myeong-sook Yoon, Israel Fisseha, So-won Suk,A Refugee Protection Within a Less-restrictive Immigration Policy and Refugee Protection in South Korea: A Policy Review of 2013's Refugee Act, Asia-Pacific Journal of Convergent Research Interchange, (2020), Vol.6, No.2, pp.1-16.

[21] Jihyun, Park, Discussion on Activation of Youth Service Learning Based on Linkage between School and Community: Focusing on Human Resources and Operational Aspects, Asia-Pacific Journal of Convergent Research Interchange, (2020), Vol.6, No.2, pp.90-107.

[22] Kyung-chul Kim, Eun-ok Kim, Ko-eun Lee, Infant's social skills are influenced by teacher-infant relationship and same age competence, International Journal of Child Warfare Promotion and Management, (2017), Vol.1, No.1, pp.3338

[23] Hyun-Min Kim, Hyoun-yong Kwon, Meta-Analysis of the Variables on Ego-Resilience of Upper Elementary Students, International Journal of Child Warfare Promotion and Management, (2017), Vol.1, No.2, pp.13-18.

[24] Henry Louis Gates Jr., The Signifying Monkey: A Theory of African-American Literary Criticism, Oxford University Press, (2008)

[25] Henry Louis Gates Jr., K.A. Appiah, Eds. Langston Hughes: Critical Perspectives Past and Present, New York: Amistad, (2003) 